\title{
The Story of a Ship Journey, Malaria, and the HBB Gene IVS-II-745 Mutation: Circassian Immigration to Cyprus
}

\author{
Mahmut C. Ergoren ${ }^{1,2}$ Sehime G. Temel ${ }^{3(0)}$ Gamze Mocan ${ }^{1,4}$ Munis Dundar ${ }^{5(0)}$
}

${ }^{1}$ Department of Medical Genetics, Faculty of Medicine, Near East

Address for correspondence Mahmut C. Ergoren, PhD, Department University, Nicosia, Cyprus

2 Rare Diseases Research Group, DESAM Institute, Near East of Medical Genetics, Faculty of Medicine, Near East University, 99138 University, Nicosia, Cyprus

${ }^{3}$ Department of Medical Genetics, Faculty of Medicine, Bursa Uludag University, Bursa, Turkey

${ }^{4}$ Department of Medical Pathology, Faculty of Medicine, Near East University, Nicosia, Cyprus

${ }^{5}$ Department of Medical Genetics, Faculty of Medicine, Erciyes University, Kayseri, Turkey

Global Med Genet 2021;8:69-71.

\begin{abstract}
Keywords

- Circassians

- $\beta$-thalassemia

- IVS-II-745

- Cyprus

- malaria

- genetic fitness

Background During 19th century, the Circassians were secluded from their lands and forced to migrate to Ottoman Empire properties. Approximately 2,346 Circassians were exiled from Istanbul to Cyprus Island. During the deportation journey, many of Circassian passed away in consequence of malaria and unknown reasons. Overall, 1,351 survivor Circassians managed to reach the island, however, many of them had faced with endemic malaria again in Cyprus. An autosomal recessive hematological disorder thalassemia was the second endemic health condition after malaria, whereas thalassemia carriers show resistance to malaria infections.

Materials and Methods A large Cypriot family with 57 members whose grandparents were supposed to be in that ship journey has been investigated in this study. Polymerase chain reaction (PCR)-amplification refractory mutation system (ARMS) analysis technique was used for genotyping the $H H B$ gene.

Results The human $\beta$-globin (HBB) gene c.316-106C > G (IVS-II-745) (II-745) heterozygous variation have been detected.

Conclusion Overall, this study is a very good example for a typical natural selection. In this case, one single gene point mutation did not limit survival in the society; natively, it increased their survival changes to form new colonization and the inheritance of the mutation to the next generations.
\end{abstract}

\section{Introduction}

During the 19th century, the autochthonous Circassians (Adyghe, Cherkess) of the Caucasus, who resisted to dominate the Eurasian Basin, were driven away from the mainland

published online March 16, 2021
DOI https://doi.org/ 10.1055/s-0041-1726336. ISSN 2699-9404. as a consequence of "The Great Game" between the British Empire, the Ottoman Empire, and the Russian Tsarist. All Circassian tribes, particularly near the coastal zone or around Krasnaya Polyana (Red Plateau) region, were relentlessly deported in view of the geopolitical anxiety of Russia. The

(C) 2021. The Author(s).

This is an open access article published by Thieme under the terms of the Creative Commons Attribution License, permitting unrestricted use, distribution, and reproduction so long as the original work is properly cited. (https://creativecommons.org/licenses/by/4.0/)

Georg Thieme Verlag KG, Rüdigerstraße 14, 70469 Stuttgart, Germany 
Table 1 Frequency and regional distribution of IVS-II-745 C>G $\beta$-thalassemia mutation in Cyprus

\begin{tabular}{|l|l|l|l|l|l|}
\hline Larnaca/Famagusta region & Limassol region & Nicosia region & Paphos region & North Cyprus & Overall \\
\hline $4.7 \%$ & $5.3 \%$ & $4.0 \%$ & $2.0 \%$ & $6.5 \%$ & $4.5 \%$ \\
\hline
\end{tabular}

number of Circassians directly killed by the Russians was estimated to be more than $500,000 .{ }^{1}$ According to the British war historian Allen, the number of Circassians placed in the Ottoman territory was more than 600,000 between the years of 1863 and $1864 .^{2}$

Immigration to Istanbul was banned due to epidemic diseases; therefore, shipment was directed to the Balkans. The Circassians, who had settled to Cyprus, were originally from Samsun, prior to Caucasus and Istanbul. Approximately 2,346 Circassians were exiled from Istanbul to Cyprus by three Ottoman flagged Aufdromachi vessels named "Revan-i Ticaret," "Hıfz-i Rahman," and "Eflak." During the deportation journey, many people could not survive due to malaria and unknown reasons. ${ }^{3}$ It was suspected that they fell victim to malaria or typhus. In fact, only 1,351 of 2,346 Circassians arrived to Cyprus.

An autosomal recessive hematological disorder, $\beta$-thalassemia, was one of the most serious endemic health conditions in Mediterranean region after malaria. ${ }^{4-6}$ During 1944 to 1946 Dr. Alan Fawdry was first to report thalassemia in Cyprus ${ }^{5}$ and the control of malaria was successful in Cyprus between the years of 1946 and $1950 .^{7}$ Haldane suggested that heterozygous carriers for $\beta$-thalassemia are less predispose to severe malarial infections, since cells containing reduce or absent synthesis of globin chains are not very conductive to malarial parasite expansion properly within the erythrocytes. ${ }^{8}$ Previous studies have revealed that five mutations were detected amongst the Turkish Cypriots $^{9,10}$ and Greek Cypriots. ${ }^{11}$ The results were generally similar IVS-I-110 $(\mathrm{G} \rightarrow \mathrm{A})$ 74.1\%, IVS-I-1 $(\mathrm{G} \rightarrow \mathrm{A})$ 7.3\%, IVS-I-6 $(\mathrm{T} \rightarrow \mathrm{C}) 7.8 \%$, IVS-II-745 $(\mathrm{C} \rightarrow \mathrm{G}) 6.5 \%$, codon $39(\mathrm{C} \rightarrow \mathrm{T})$ 0.9\%, unknown $3.4 \%$ were the frequency of Turkish Cypriots and IVS-I-110 $(\mathrm{G} \rightarrow \mathrm{A})$ 79.0\%, IVS-I-6 $(\mathrm{G} \rightarrow \mathrm{A}) 6.3 \%$, IVS-I-I $(\mathrm{T} \rightarrow \mathrm{C})$ $6.0 \%$, IVS-II-745 $(\mathrm{C} \rightarrow \mathrm{G}) 4.1 \%$, codon $39(\mathrm{C} \rightarrow \mathrm{T}) 1.8 \%$, and the other $3.4 \%$ were the frequency for Greek Cypriots, respectively (-Table 1) ${ }^{10,11}$ The mutation denoted as IVS-II-745 $(C \rightarrow G)$ was introduced to the Eastern Mediterranean region during Muslim groups movement living in former Turkish territories to Southern Europe as a consequence of the Ottoman Empire falling (starting from 1914 AD), consequently contributing to a racial admixture. ${ }^{12,13}$ In addition, the IVS-II-745 $(C \rightarrow G)$ mutation was detected in less heterogenic regions, for instance Northern, Southern, and Western Anatolia ${ }^{14-16}$ ( - Table 2). In this study, we aimed to trace the introducer of the mutation in the island and explained natural selection process.

\section{Materials and Methods}

\section{Patients and Genotyping}

Venous blood was collected with ethylenediaminetetra-acetic acid (EDTA) tubes from 57 Turkish Cypriot family mem- bers and genomic DNA was isolated using PureLink Genomic DNA Mini Kit (Thermo Fisher Scientific, Waltham, Massachusetts, United States) for sequencing. Medical history was questioned and written informed consent form obtained from all the patients. DNA extraction was conducted under a class-II laminar flow using autoclaved pipets to minimize the risk of contamination in a class-II laminar flow hood. All solutions and equipments were ultraviolet (UV) treated to prevent any potential contamination. Mutation screening was performed in the human $\beta$-globin (HBB) gene using polymerase chain reaction (PCR)-amplification refractory mutation system (ARMS) analysis for point mutations as described by Sozuöz et al. ${ }^{10}$ Informed consents were obtained from all participants. This study has been approved by the institutional ethics committee (registration number: YDU/2020/77-978).

Table 2 Frequency and regional distribution of IVS-II-745 C > G $\beta$-thalassemia mutation across the world

\begin{tabular}{|l|l|}
\hline Country & Frequency (\%) \\
\hline Syria & 16.6 \\
\hline Jordan & 14.2 \\
\hline Egypt & 7.2 \\
\hline North Cyprus & 6.5 \\
\hline Greece & 6.3 \\
\hline Italy & 5.0 \\
\hline Turkey & 5.0 \\
\hline Germany & 4.3 \\
\hline Cyprus & 4.1 \\
\hline Morocco & 4.0 \\
\hline Lebanon & 4.0 \\
\hline Macedonia & 3.9 \\
\hline Bulgaria & 3.7 \\
\hline Iran & 3.7 \\
\hline Czech Republic & 3.5 \\
\hline Slovakia & 2.8 \\
\hline Tunisia & 7.5 \\
\hline Israel & 2.5 \\
\hline Spain & 1.7 \\
\hline United Kingdom & 1.7 \\
\hline Azerbaijan & 0.8 \\
\hline Argentina & 0.7 \\
\hline Portugal & 0.4 \\
\hline Sri Lanka & 0.2 \\
\hline India & 0.04 \\
\hline
\end{tabular}




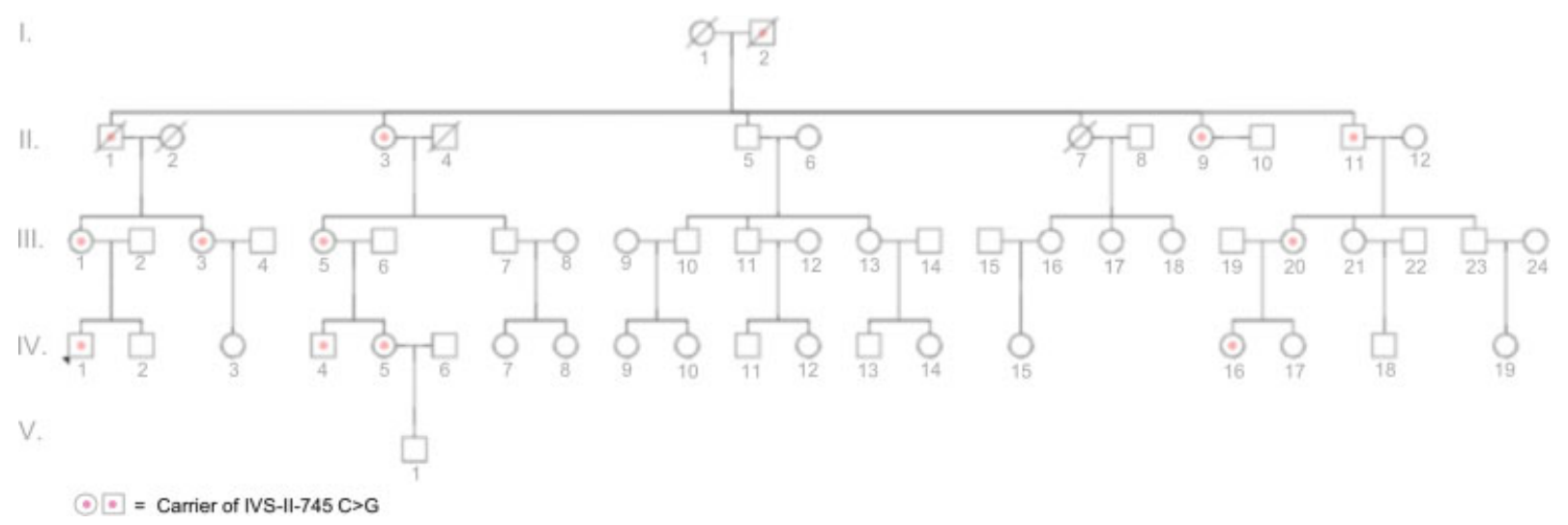

Fig. 1 Pedigree of the Cerkez family. Affected family members by a heterozygous IVS-II-745 $(C \rightarrow G)$ are shown in the pedigree.

\section{Results}

\section{Studied Patients and Genotyping}

Fifty-seven members of the conserved Circassian family members whose grandparents were driven away from their mainland and migrated to Cyprus in early 1860s was screened for common thalassemia-causing mutations using PCR-ARMS. The sequence analysis revealed heterozygous IVS-II-745 $(C \rightarrow G)$ mutation in 12 family members (II:1, II:3, II:9, II:11, III:1, III:3, III-5, III:20, IV:1, IV:4, IV:5, IV:16; - Fig. 1).

\section{Discussion}

The family data can be used to summarize that this studied family has relations to Caucasia, it further demonstrates that ancestors of the family were at an advantage during the migration to Cyprus, as this mutation protected them from malaria. The example provided in this study represents a very example for natural selection scenario. Overall, this current study indicated that the HBB gene IVS-II-745 $(\mathrm{C} \rightarrow \mathrm{G})$ did not limit survival, in fact it enhanced the survival changes of the migrating family members, allowing them to form new colonization, and inheritance of the mutation to their offspring.

\section{Conclusions}

1. The HBB gene IVS-II-745 $(\mathrm{C} \rightarrow \mathrm{G})$ mutation has been studied in a larger family.

2. This study involves a standard population genetics topic including migration, gene flow, natural selection, and adaptation.

3. This study contributes both to the fields of history and human genetics.

Conflict of Interest

None declared.

Acknowledgment

The authors would like to thank Dr. Muhittin Ozsaglam for assistance with historical support and for comments that greatly improved this article.

\section{References}

1 Abreg A. Geçmişten Günümüze Kafkasların Trajedisi. Istanbul: Kafkas Vakfi Yayinlari; 2006:43

2 Allen WED. Muratoff P. 1828-1921 Türk-Kafkas Sınırındaki Harplerin Tarihi. Genelkurmay Başkanlığı Yayınları Ankara, Turkey: Genelkurmay Bașkanlığı; 1966:104

3 Sasmaz M. Immigration and Settlemen of Circassian in the Ottoman Empire on British Documents 1857-1864. Osmanlı Tarihi Araştırma ve Uygulama Merkezi Dergisi 1999;09:331-336

4 World Health Organization (WHO); Community control of hereditary anemias, memorandum from a WHO meeting. Bull World Health Organ 1983;61(01):63-80

5 Modell B, Berdoukas V. Thalassaemia in Cyprus. In: Modell B, Berdoukas V, eds. The Clinical Approaches to Thalassaemia. London, United Kingdom: Grune \& Stratton; 1984:263-277

6 Bozkurt G. Results from the north cyprus thalassemia prevention program. Hemoglobin 2007;31(02):257-264

7 Kent G. Total victory over malaria. Read Dig 1951:77-79

8 Haldane JBS. The rate of mutations of human genes. Hered Suppl 1949;35:267-273

9 Aziz M. History of prevention of malaria in Cyprus. Cyprus Med J 1947;1(02):13-17

10 Sozuöz A, Berkalp A, Figus A, Loi A, Pirastu M, Cao A. $\beta$ thalassaemia mutations in Turkish Cypriots. J Med Genet 1988;25(11): 766-768

11 Baysal E, Indrak K, Bozkurt G, et al. The $\beta$-thalassaemia mutations in the population of Cyprus. Br J Haematol 1992;81(04): 607-609

12 Kountouris P, Kousiappa I, Papasavva T, et al. The molecular spectrum and distribution of haemoglobinopathies in Cyprus: a 20-year retrospective study. Sci Rep 2016;6:26371

13 Grmek MD. -Malaria in the eastern Mediterranean in prehistory and antiquity-. Parassitologia 1994;36(1,2):1-6

14 Orkin SH, Kazazian HH Jr., Antonarakis SE, et al. Linkage of betathalassaemia mutations and beta-globin gene polymorphisms with DNA polymorphisms in human beta-globin gene cluster. Nature 1982;296(5858):627-631

15 Tadmouri GO, Başak AN. $\beta$-thalassemia in Turkey: a review of the clinical, epidemiological, molecular, and evolutionary aspects. Hemoglobin 2001;25(02):227-239

16 Tadmouri GO, Tüzmen S, Ozçelik H, et al. Molecular and population genetic analyses of beta-thalassemia in Turkey. Am J Hematol 1998;57(03):215-220 